\title{
Mapping inshore fisheries: Comparing observed and perceived distributions of pot fishing activity in
} Northumberland

Rachel A Turner ${ }^{a 1^{*}}$, Nicholas VC Polunin ${ }^{a}$, Selina M Stead ${ }^{a}$

a School of Marine Science and Technology, Newcastle University, Newcastle upon Tyne, NE1 7RU, UK

${ }^{1}$ Present address: Centre for Resource Management and Environmental Studies, University of the West Indies, Cave Hill Campus, St Michael, Barbados, BB1100 / Environment and Sustainability Institute, University of Exeter, Penryn Campus, Cornwall, TR11 9FE, UK

* Corresponding author

Email: r.turner@exeter.ac.uk

\section{Highlights}

- We compare distributions of inshore potting activity mapped by two data sources.

- Maps based on vessel sightings and interview data are correlated at multiple ports.

- Vessel sightings and map-based interview data have unique limitations and merits.

- Triangulation of datasets is recommended to inform marine spatial planning.

\begin{abstract}
Marine spatial planning (MSP) is increasingly promoted as part of an ecosystem-based approach to marine resource management. Impacts of MSP may be particularly great in inshore fisheries, yet despite their vulnerability, assessing potential impacts of spatial measures on inshore fisheries is limited by data scarcity, and the comparability of patterns of fishing activity produced by different data sources is poorly understood. This study contributes to the debate around information needs for MSP by describing the distribution of lobster potting activity at four ports in Northumberland, UK, using two sources of spatial data: observed fishing vessel sightings by patrol vessels and perceived fishing activity elicited through interviews with local fishers. The comparability of the distributions of potting activity mapped by the two datasets was explored using Mantel tests and overlap of fishing hotspots identified. Fishing activity at all ports tended towards an aggregated or patchy distribution, with hotspots located in inshore areas in close proximity to vessels' home ports. The two datasets were correlated at each port, though the strength of correlation varied among ports, being greater in ports with more highly aggregated fishing activity. Results suggest that vessel sightings are likely to better represent variable intensity of fishing activity, while interview data may more accurately capture the absolute extent of grounds important to fishers. This study highlights some of the merits and limitations of two available data sources currently used to inform fisheries management and marine conservation planning, and outlines an approach to assessing the consistency of datasets in describing the spatial distribution of activity. Given the limitations of individual datasets, we recommend triangulation of available data to inform MSP, alongside qualitative data on fishers' behaviour.
\end{abstract}

Keywords: marine spatial planning; inshore fisheries; interview data; vessel sightings; GIS

\section{Introduction}

In the context of declining fisheries and degradation of marine ecosystems globally, spatial management is increasingly promoted as part of an ecosystem-based approach to marine resource management [1-3]. This trend is illustrated by the growing application of marine spatial planning (MSP) approaches, which seek to balance ecological, economic, and social objectives through comprehensive, integrated planning of multiple uses of the marine environment [4]. The emergence of MSP has created greater demand for data on the spatial distribution of human 
uses of the marine environment. Data are sought to quantify impacts of resource use, understand areas of conflict, and assess potential implications of proposed management measures $[5,6]$.

Fisheries constitute a pervasive use of the marine environment worldwide, yet have proved difficult to map due to limited data collection, availability and consistency, which result partly from the complex and changeable nature of fisheries over space and time [7]. Information on the distribution of fishing activity is needed to quantify the relative intensity of fishing pressure, understand fishery dynamics and inform fisheries management measures [7-9]. Understanding the distribution of fishing activity is important to assess potential impacts of MSP on fisheries, including identifying areas of economic importance to the fishing industry, and assessing possible loss of income or fishing effort displacement due to spatial closures $[10,11]$. Taking into account these impacts and likely behavioural responses of fishers may be critical to the success of spatial management measures [12-15].

Impacts of MSP may be particularly great in inshore fisheries. For example, diverse habitats, biological complexity, and multiple uses of inshore marine areas, combined with the relative legal simplicity of managing areas within national territorial waters has meant that MPA designation in Europe has concentrated in inshore areas [16]. Spatial management is likely to have greater impacts on less mobile fishers $[17,18]$, including those confined to limited fishing grounds by smaller, less powerful vessels, and those targeting species that are more sedentary or have habitat requirements common to inshore areas. Displacement of fishing activity may incur additional costs for smallscale fishers, and may disrupt informal social arrangements concerning use of fishing grounds by failing to take account of how fishing grounds are linked to communities $[4,19]$. Small-scale fishers are also likely to lack political influence needed in negotiations with other stakeholders competing for use of the marine environment [20].

Despite their vulnerability, assessing potential impacts of spatial management measures on inshore fisheries is limited partly by scarcity of spatial data. A variety of methods have been used to map the distribution of fishing activity, including information submitted through fishers' logbooks [21-25], active recording of vessel sightings data by enforcement agencies [26], and automated recording of vessel positions through vessel monitoring systems (VMS) $[6,21,22,27-32]$. However, smaller-scale inshore fisheries have historically been subject to less consistent data reporting schemes than larger vessels and their complexity makes data collection challenging [25,33]. If the interests of inshore fisheries are to be fully considered, integrating the spatial representation of their activity into planning processes is critical. Credible maps that support fishers' claims to fishing grounds have potential to help mitigate against negative impacts of MSP [20].

Lack of knowledge of the distribution of inshore fishing has led to increasing use of interviews with fishers to elicit spatial data [34-36]. This acknowledges the role of local knowledge and expertise to corroborate or supplement scientific knowledge, and for cooperation with fishers to help highlight areas of conflict that may influence the success of MSP [37-39]. Data collected can be combined with other spatial information using geographic information systems (GIS) and incorporated in spatial analysis [19,34,40-45]. Interview data may provide a better representation of resource use at fine spatial scales than other socio-economic data [46], yet there remain methodological questions as to how such data compare with those collected through more formal monitoring programmes. Recent research has focused on developing methods to integrate and triangulate local and scientific knowledge to inform policy and management, recognising that different types of knowledge have different values and limitations $[19,38,47-49]$. However, map-based interviews are commonly used to provide spatial information in situations where fine scale scientific data is unavailable [35], therefore it is often not possible to compare the outputs produced from two data types at the same scale. The need to assess the comparability of the patterns observed by different data sources has been recognised, but limited work has been undertaken in this area so far $[26,34]$. 
The goal of this paper is to contribute to the debate around MSP information needs by comparing two sources of spatial information on the inshore potting fishery in Northumberland, north east England. In the context of on-going consideration of spatial restrictions on static gear fisheries within the district, Northumberland represents a useful case study to assess the value of different data sources in providing information on the distribution of fishing activity. The datasets are illustrative of those currently available to inform fisheries management and marine conservation planning in the UK and many other contexts. The specific objectives of this study are to: 1) describe the distribution of lobster potting activity in Northumberland using observed fishing vessel sightings by patrol vessels and perceived fishing activity elicited through interviews with local fishers; and 2) explore the relationship between the distributions of potting activity mapped by the two datasets at four ports in Northumberland. Analysis was undertaken at port level to allow comparison of agreement between datasets at locations with different fleet characteristics and levels of patrol effort.

\section{Methods}

\subsection{Study area}

In the UK, where vessels $<10 \mathrm{~m}$ comprise over $75 \%$ of the fishing fleet, inshore fishing sustains many livelihoods and is vital to the coastal economy $[16,50,51]$. The North Sea is one of the most congested in the world and the UK, like many other countries, is more frequently employing MSP as a mechanism to manage contested space issues [20]. Towards meeting international commitments under the Convention on Biodiversity and European Marine Strategy Framework Directive, the UK Government has committed to developing a network of marine protected areas (MPAs) covering over $25 \%$ of English seas by 2016, including marine conservation zones (MCZs) [52]. Twenty-seven MCZs were designated in 2013 under the UK Marine and Coastal Access Act (2009), and further phases of MCZ designation are expected by 2016 [53]. MCZ designation is principally intended to protect marine biodiversity, but decisionmaking is also required to consider socio-economic impacts on resource users [54], recognising that MPA network design must balance biodiversity conservation and socio-economic viability [55]. Inshore Fisheries and Conservation Authorities (IFCAs) are responsible for aspects of inshore fisheries management and enforcement in England and Wales, including MCZ management. The Northumberland coast is home to a wide range of ecologically important habitats [56], yet to date, $M C Z$ designations have included only $0.39 \mathrm{~km}^{2}$ of intertidal and estuarine habitat in within the NIFCA district [57].

This study focuses on four major shellfish ports (Blyth, Amble, Seahouses and Holy Island) in the Northumberland IFCA (NIFCA) district, a $160 \mathrm{~km}$ coastal strip extending out to 6 nautical miles (nmi). The potting fishery is a multispecies fishery targeting predominantly European lobster (Homarus gammarus), brown crab (Cancer pagurus) and velvet crab (Necora puber). Target species are fished using pots, which are fished in "fleets" of 20-40. Pots are baited and deployed, and typically left to soak for one to two days. Potting vessels in the district are between 4 and $12 \mathrm{~m}$ in length, and the majority of vessels work within $12 \mathrm{nmi}$ of the coast. There are no legal restrictions on where fishers may fish, though in 2009 NIFCA introduced a limit of 800 on the number of pots that any vessel could use within its area of jurisdiction.

\subsection{Observed fishing activity}

NIFCA collects data on fishing vessel sightings (hereafter 'sightings') during routine enforcement patrols. These currently represent the most extensive formal data on the distribution of $<10 \mathrm{~m}$ vessels. Sightings records include the name, registration and home port of fishing vessels, their geographic position and observed activity. Sightings recorded within NIFCA district boundaries during 2004-2008 (Table 1) were verified by cross-referencing with NIFCA permit databases and Fishery Officers to identify inconsistencies in vessel details, ports or fishing activities. Sightings 
of crab and lobster potting (recorded as one activity; $n=1982)$ ) were extracted for the ports studied and mapped using ArcView GIS version 9.2 (Figure 1a) [58].

Table 1. Sightings data and patrol route information 2004-2008, obtained from NIFCA

\begin{tabular}{llllllll}
\hline Year & \multicolumn{9}{c}{ Vessel sightings by port } & NIFCA & $\begin{array}{l}\text { Patrol routes } \\
\text { available (\%) }\end{array}$ \\
\cline { 2 - 6 } & Blyth & Amble & Seahouses & Holy Island & Total & Patrols & ava \\
\hline 2004 & 119 & 201 & 230 & 46 & 596 & 104 & $90(87)$ \\
2005 & 120 & 167 & 144 & 33 & 464 & 99 & $47(47)$ \\
2006 & 137 & 167 & 113 & 21 & 438 & 86 & $0(0)$ \\
2007 & 106 & 94 & 65 & 9 & 274 & 85 & $49(58)$ \\
2008 & 109 & 73 & 28 & 0 & 210 & 75 & $56(75)$ \\
Total & 591 & 702 & 580 & 109 & 1982 & 449 & $242(54)$ \\
\hline
\end{tabular}

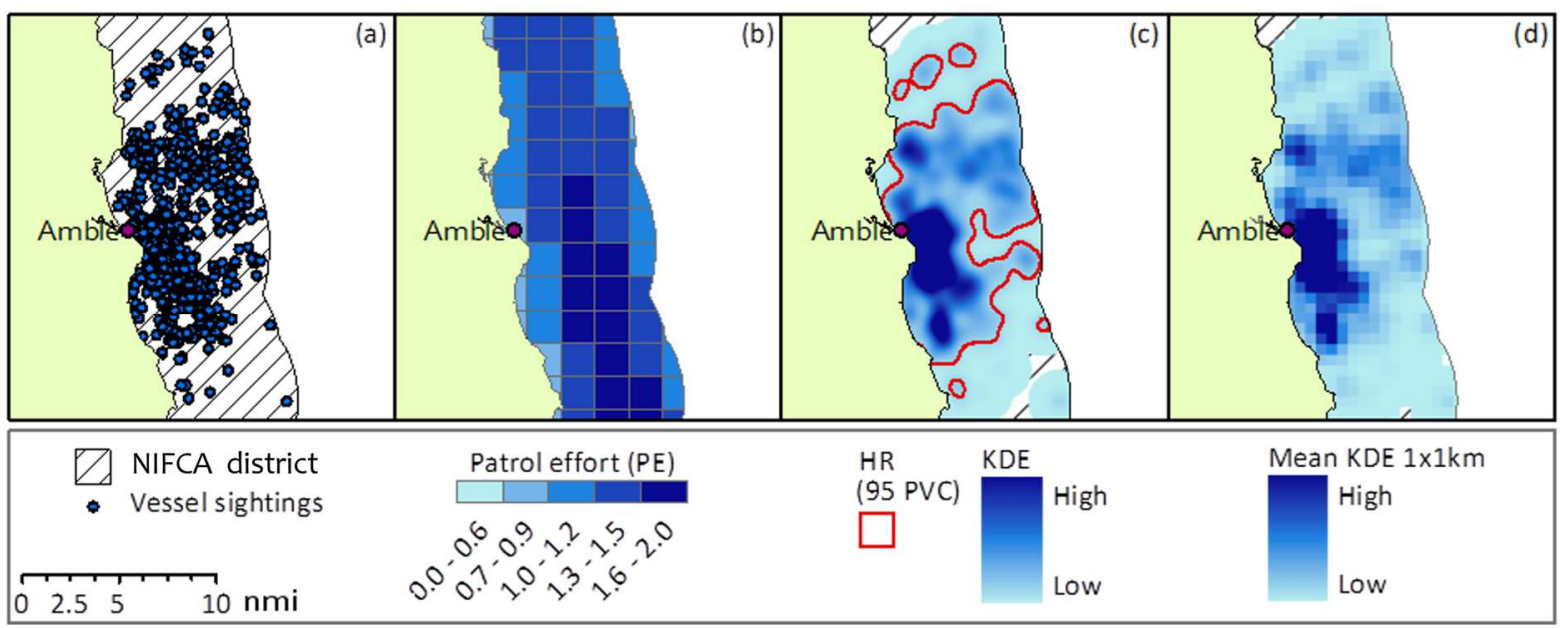

Figure 1. Illustration of vessel sightings data analysis: a) point data representing individual sightings, b) $3 \times 3 \mathrm{nmi}$ grid cells weighted by patrol effort, c) kernel density estimate (KDE) with 95 percent volume contour (home range) d) mean values $(1 \times 1 \mathrm{~km}$ grid)

Analysis accounted for possible bias in sightings of fishing activity due to timing and routes of patrols, which are driven by enforcement priorities, and the mooring location of the patrol vessel. Patrol route information for $54 \%$ of patrol routes during 2004-2008 was obtained (Table 1). Inspection of patrol routes suggested consistent route patterns over time, thus the information was considered representative of patrol effort distribution during the study period, and data from all years were pooled. A $3 \mathrm{nmi}^{2}$ grid was superimposed on the NIFCA district, assuming that visibility would be sufficient for any fishing vessel within the same grid square to be seen by the patrol vessel [59]. Patrol effort (PE) was estimated using a combination of the number of patrols passing through each grid cell, and the distance of each grid cell to the nearest mapped patrol route (Figure 1b). Sightings in grid squares containing no patrol routes implied a degree of patrol effort unaccounted for by patrols passing through the cell. It was therefore assumed that patrol effort decreased linearly with distance from patrol routes (Equation 1).

$P E=\left(1-\frac{n}{N}\right)+\left(1-\frac{D_{\max }-D_{g}}{D_{\max }-\mathrm{D}_{\min }}\right)$

Equation 1.

The first part of the equation is based on the proportion of patrols passing through each grid cell, where $n=$ number of patrols passing through a grid cell and $\mathrm{N}=$ total number of patrols. The second part is based on a linear distance decay function in which the inverse Euclidean distance of each cell to patrol points is normalised as a proportion of the maximum possible distance: $D_{\max }=$ maximum distance to patrol route, $D_{g}=$ grid square distance from patrol route, and $D_{\min }=$ minimum distance to patrol route. 
To allow analysis at port level, sightings during 2004-2008 were pooled due to the limited number of sightings per port per year (Table 1). The assumption that there was no change over time in the distribution of observed activity was tested by comparing the distribution of sightings during each year across the $3 \mathrm{nmi}^{2}$ grid using the Mantel test in the Vegan library in the statistical package $\mathrm{R}[60,61]$. Mantel tests perform a correlation between two distance matrices summarising pairwise similarities among grid cells, which allows for autocorrelation in spatial data [62]. Where standardised values are used, values of the Mantel statistic $\left(r_{M}\right)$ fall between -1 and +1 , behaving like a correlation coefficient; significance levels are obtained using a reference distribution obtained through permutation [63]. Correlations were found between all years $\left(r_{\mathrm{M}}=0.590-0.766\right.$, significance $\left.\leq 0.001\right)$, suggesting similar interannual spatial patterns of observed fishing activity.

Patrol effort was used to weight sightings in each grid square, negatively weighting those in areas of high patrol effort and vice versa. Weighted point data were transformed to a continuous surface (Figure 1c), providing more information on the relative intensity of fishing activity in different areas [45]. The probability distribution of fishing activity was assessed from the sample of weighted sightings using a kernel density estimate (KDE) [64], producing a raster image of cell size $100 \mathrm{~m} \times 100 \mathrm{~m}$. A smoothing factor of $1000 \mathrm{~m}$ (which determines the area around a given location within which data points contribute to the probability estimate for that point [65]), was chosen for the KDE analysis following discussion of a range of options with local fishers and NIFCA Fishery Officers.

Percent volume contours, which delineate contours containing a specific proportion of the probability density distribution, were used to estimate the home range of potting fleets at each port. Home range is defined in this context as the smallest area accounting for a specified proportion of the distribution of vessel activity from each port [following 61]. To minimise the influence of positional errors or vessel mis-identification in outlying data points, the 95 percent volume contours, delineating the area in which $95 \%$ of vessel sightings are expected to occur based on the sample data, was calculated for each port [64]. Polygons were clipped to the extent of the NIFCA district and mean values for each cell were derived for a $1 \times 1 \mathrm{~km}$ grid (Figure 1d).

\subsection{Perceived fishing activity}

Semi-structured interviews were conducted during March-September 2009 with 41 fishers (95\% of active fishers) at the four ports (Table 2). The target population comprised skippers of active fishing vessels targeting lobster and crab, who typically spent over two thirds of their time fishing within the NIFCA district (Table 2). Initial contact with fishers was made through NIFCA officers. Subsequent interviewees were contacted via snowballing methods, or by approaching fishers on the quayside [67]. Over $90 \%$ of active fishers were interviewed in each port, thus the sample was considered representative of the target population. 
Table 2. Interviewee characteristics and fishing practices in each port

\begin{tabular}{|c|c|c|c|c|}
\hline \multirow[b]{2}{*}{ Port characteristics } & \multicolumn{4}{|l|}{ Port } \\
\hline & Blyth & Amble & Seahouses & Holy Island \\
\hline Active potting vessels & 11 & 17 & 9 & 6 \\
\hline Number interviewed (\%) & $10(91)$ & $16(94)$ & $9(100)$ & $6(100)$ \\
\hline Mean age, years (SE) & $47(3)$ & $52(3)$ & $42(4)$ & $56(5)$ \\
\hline Mean fishing experience, years (SE) & $23(3)$ & $29(4)$ & $25(3)$ & $40(5)$ \\
\hline Mean vessel length, m (SE) & $9.0(0.56)$ & $7.8(0.47)$ & $9.9(0.35)$ & $8.5(0.51)$ \\
\hline Mean engine size, $\mathrm{kW}$ (SE) & $106(28)$ & $56(11)$ & $187(43)$ & $119(39)$ \\
\hline Mean number lobster pots (SE) & $410(60)$ & $388(55)$ & $636(74)$ & $575(101)$ \\
\hline Interviewees targeting lobster (\%) & $10(100)$ & $16(100)$ & $9(100)$ & $6(100)$ \\
\hline Interviewees targeting brown crab (\%) & $9(90)$ & $14(82)$ & $9(100)$ & $6(100)$ \\
\hline Interviewees targeting velvet crab (\%) & $7(70)$ & $14(82)$ & $7(78)$ & $6(100)$ \\
\hline Mean months worked per year ( $n$ ) & $8.2(10)$ & $10.6(16)$ & $11.3(9)$ & $12(5)$ \\
\hline Mean \% time outside $6 \mathrm{nmi}(\mathrm{n})$ & $2(9)$ & $21(14)$ & $34(9)$ & $10(6)$ \\
\hline
\end{tabular}

Interviews lasted 30-180 minutes and included enquiries about historical and current fishing activity, gear use, details of fishing vessels, and a map-based component. The approach taken followed that of previous studies designed to elicit fishers' spatial knowledge $[19,34-36,43,68]$. Interview questions were piloted with fishers outside the target population to determine suitable wording and an appropriate style and scale of charts. Interviewees were prompted to indicate areas that they fish, including areas specifically targeted in different seasons or for different species, and any seasonal or temporal changes in fishing area. Responses were recorded on local admiralty charts at scales of 1:115,000 -1:125,000. Additional information such as type of ground or seasonality of use was noted.

Maps were obtained from 40 of the 41 interviewees, and were scanned and georeferenced (Figure 2a). Using data on the seasonal use of each mapped polygon and the total quantity of gear worked by each fisher, fishing effort (pot months $\mathrm{km}^{-2} \mathrm{yr}^{-1}$, where one pot month is equal to one pot worked for one month) was estimated for each polygon (Figure 2b). For each month, the number of pots worked by each fisher was distributed evenly across the total area of polygons fished. Polygons were overlaid at each port, and fishing effort summed where polygons overlapped. To enable comparison of interview and sightings data, polygons were clipped to the NIFCA district and converted to a raster image (Figure $2 \mathrm{c}$ ), from which mean values per cell were derived for a $1 \times 1 \mathrm{~km}$ grid (Figure $2 \mathrm{~d}$ ). 


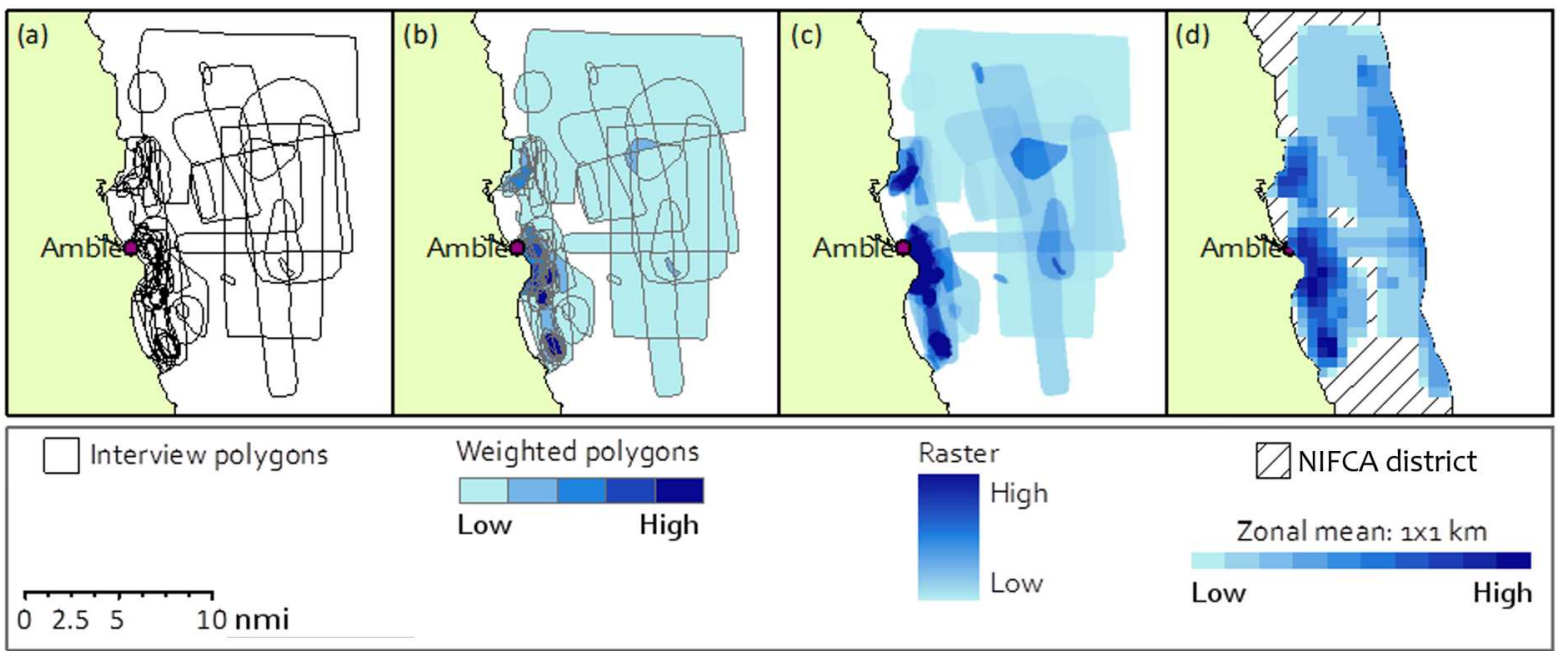

Figure 2. Illustration of interview data analysis: a) individual polygons geo-referenced, b) weighted polygons overlaid, c) overlapping polygon values summed and converted to raster image, d) statistics calculated for a $1 \times 1 \mathrm{~km}$ grid, clipped to NIFCA district.

\subsection{Data integration and analysis}

Measures of observed and perceived fishing activity were derived for each grid cell in a $1 \times 1 \mathrm{~km}$ grid at each port. This scale was considered the most detailed level of analysis possible given potential inaccuracies of interview maps and error resulting from choice of smoothing factor in KDE analysis. Perceived and observed fishing activity distributions at each port were compared using the Mantel test performed on Euclidean distance matrices.

Hotspots of high fishing activity in both datasets, defined as the area in which $50 \%$ of vessel sightings are expected to occur based on the sample data, were identified using kernel density estimates and percent volume contours. To enable a direct comparison of hotspots, the raster image produced using interview data was converted to weighted point data for analysis. The total area of hotspots mapped by observed and perceived data was calculated, and the area over which the two data sets coincided was expressed as a percentage of the total area.

To assess whether the distribution of fishing effort differed from a random distribution at each port, values from modelled grid cells were standardised and the dispersion for each dataset coefficient (variance : mean ratio, denoted as $C$ ) was calculated at each port [69]. A random distribution was indicated by a value of $C=1$, while increasing values indicated a greater degree of aggregation or patchiness. Measures of dispersion for both observed and perceived distributions of fishing activity at each port were compared to measures of consistency between the two datasets (Mantel statistics and hotspot overlap).

\section{Results}

\subsection{Distribution of fishing activity}

\subsubsection{Fishing grounds: extent and aggregation}

Maps of observed and perceived distributions of potting activity showed similar overall patterns (Figure 3), however the absolute extent of mapped fishing grounds differed between the two datasets at each port. Port home ranges estimated from sightings data ranged from a minimum of $78 \mathrm{~km}^{2}$ at Holy Island to a maximum of $265 \mathrm{~km}^{2}$ at Amble (Table 3). In contrast, the largest area of fishing ground mapped by fishers was at Holy Island. At all ports, fishing grounds mapped by fishers were more extensive than home ranges estimated using sightings data. 
Dispersion coefficients suggested fishing activity at all ports tended towards an aggregated or patchy distribution, with fishing activity concentrated in particular areas. Highest potting activity was located in inshore areas in close proximity to vessels' home ports, and the majority of recorded activity was within $3 \mathrm{nmi}$ of shore (Figure 3). Both sightings and interview data were least aggregated at Seahouses, while the highest aggregation in sightings data was identified at Holy Island, and highest aggregation in interview data at Amble.

Table 3. Summary of interview and sightings data (to $6 \mathrm{nmi}$ ). Mantel statistics based on Pearson's product-moment correlation between dissimilarity matrices of standardised sightings data and interview data; calculations were based on 999 permutations and were all significant at $\alpha=0.001$. Estimated hotspots of fishing activity based on observed fishing activity (vessel sightings) and perceived fishing activity (interview data), and area of overlap between the two hotspots at each port.

\begin{tabular}{|c|c|c|c|c|c|}
\hline \multirow[t]{2}{*}{ Data source } & \multirow[t]{2}{*}{ Measurement } & \multicolumn{4}{|c|}{ Port } \\
\hline & & Blyth & Amble & Seahouses & Holy Island \\
\hline \multirow{6}{*}{$\begin{array}{l}\text { Sightings data } \\
(2004-8)\end{array}$} & Vessel sightings & 591 & 701 & 580 & 109 \\
\hline & Home range $\left(\mathrm{km}^{2}\right)$ & 193 & 265 & 260 & 78 \\
\hline & Dispersion (C) & 1.6 & 1.8 & 1.48 & 2.97 \\
\hline & Number of hotspots & 5 & 3 & 4 & 1 \\
\hline & Mean hotspot area $\left(\mathrm{km}^{2}\right)$ & 10.5 & 15.5 & 18.6 & 20 \\
\hline & Total hotspot area $\left(\mathrm{km}^{2}\right)$ (\% home range) & $52.5(27)$ & $46.4(18)$ & $74.4(29)$ & $20(26)$ \\
\hline \multirow{6}{*}{$\begin{array}{l}\text { Interview data } \\
\text { (2009) }\end{array}$} & Total polygons & 83 & 56 & 48 & 23 \\
\hline & Total area $\left(\mathrm{km}^{2}\right)$ & 284 & 336 & 341 & 350 \\
\hline & Dispersion (C) & 1.96 & 2.31 & 1.39 & 1.94 \\
\hline & Number of hotspots & 4 & 3 & 3 & 1 \\
\hline & Mean hotspot area $\left(\mathrm{km}^{2}\right)$ & 14.4 & 12.2 & 34.9 & 48.6 \\
\hline & Total hotspot area $\left(\mathrm{km}^{2}\right)$ (\% of fishing grounds) & $57.8(20)$ & $36.6(11)$ & $104.8(31)$ & $48.6(14)$ \\
\hline \multirow{4}{*}{$\begin{array}{l}\text { Map } \\
\text { comparison }\end{array}$} & Mantel statistic $r_{M}$ & 0.528 & 0.676 & 0.384 & 0.832 \\
\hline & Total hotspot area $\left(\mathrm{km}^{2}\right)$ & 81.1 & 53.7 & 138.9 & 48.6 \\
\hline & Area of overlap $\left(\mathrm{km}^{2}\right)$ & 29.3 & 29.2 & 40.3 & 20 \\
\hline & Overlap as $\%$ of hotspot area & 36 & 54 & 29 & 41 \\
\hline
\end{tabular}

\subsubsection{Fishing hotspots}

Sightings and interview data suggested that hotspots of potting activity were located in inshore areas and in close proximity to ports (Figure 3a-h); 50\% of observed fishing activity occurred over an area of $20-75 \mathrm{~km}^{2}$ at each port, representing $18-29 \%$ of the estimated home range of each fleet. In comparison, $50 \%$ of perceived activity occurred within 36.6-104.8 $\mathrm{km}^{2}$ at each port, representing 11-31\% of the total mapped fishing grounds at each port (Table 3). At Amble and Holy Island all hotspots identifed overlapped among datasets (Figure 3j,h). At Blyth and Seahouses larger hotspots were mapped by both sightings and interview data, but smaller hotspots were identified by only one of the two datasets, suggesting differences between the two datasets in identifying hotspots (Figure $3 \mathrm{i}, \mathrm{k}$ ). 


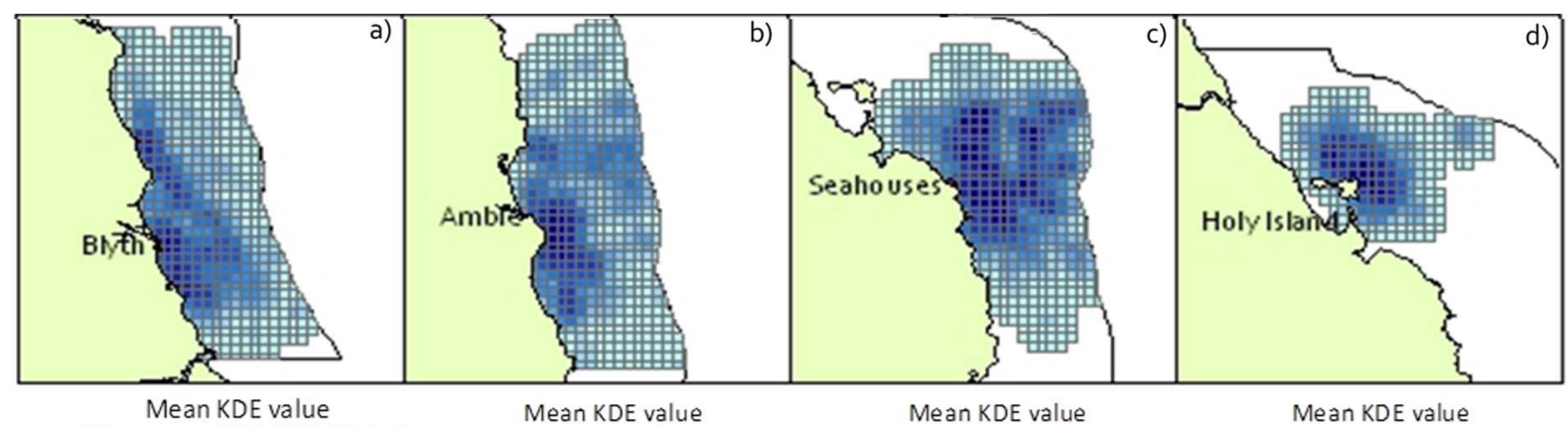

Mean KDE value

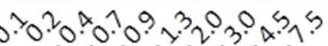

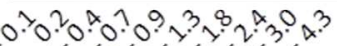

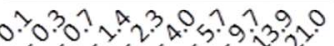

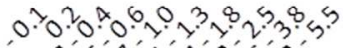

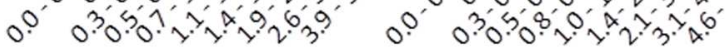

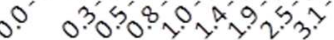

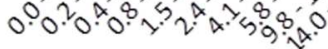

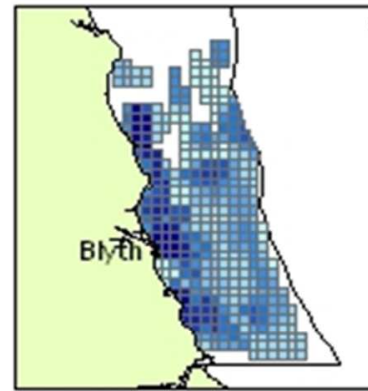

PM per sq km per year

$7^{2} 2^{6} \times 6^{0} 9^{2} \times x^{x} 2^{8}+3^{3} 6^{8}, 3^{9}$

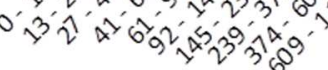

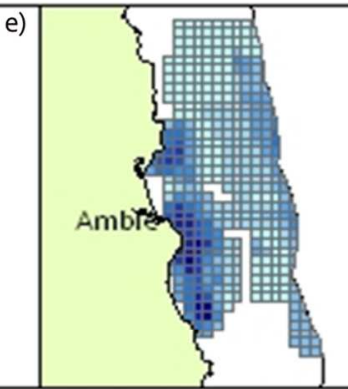

PM per sq km per year

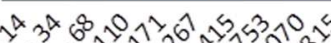

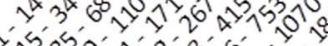

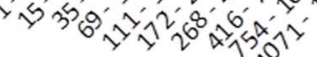

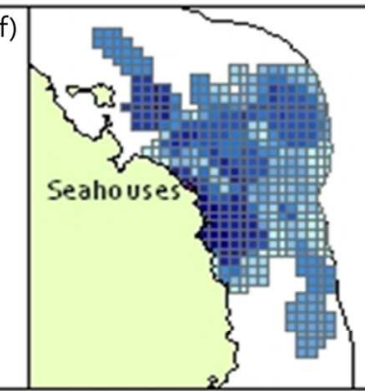

PM per sq km per year

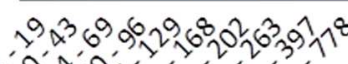

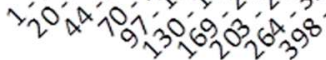

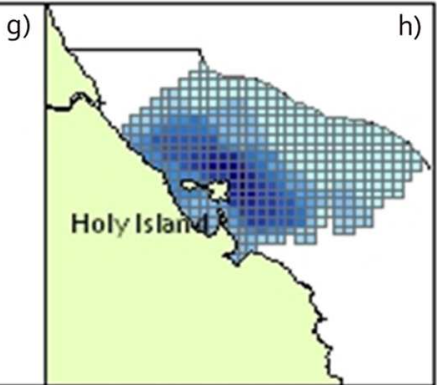

PM per sq km per year

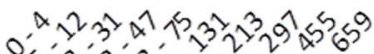

0

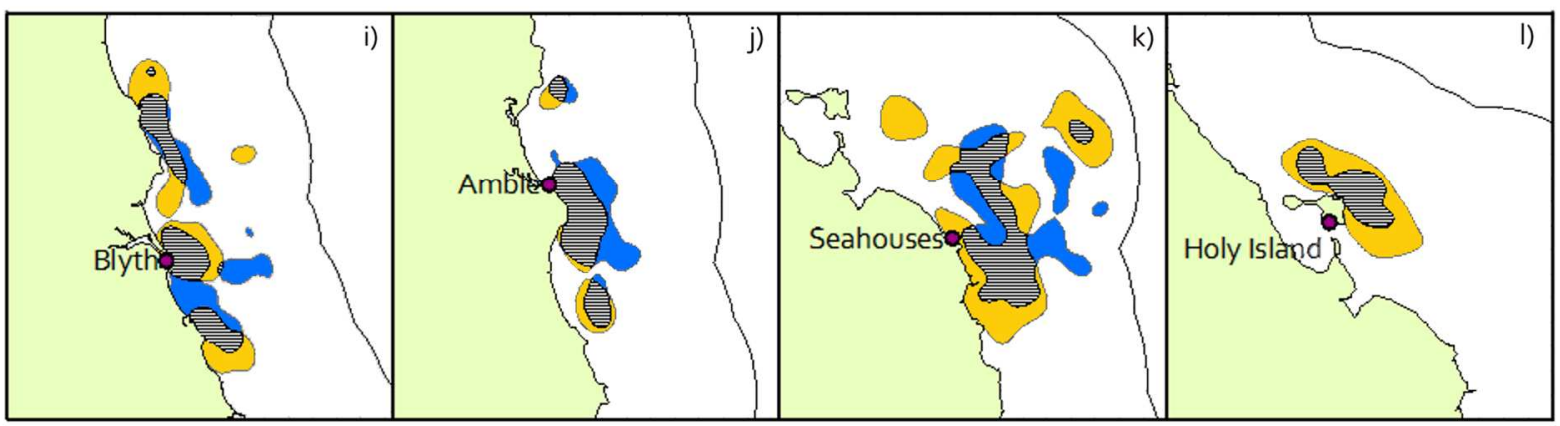

Vessel sightings

Interviews

Overlap

Figure 3. Estimated distribution of fishing activity based on: a-d) observed fishing activity (vessel sightings, based on kernel density estimates (KDE)), and e-h) perceived fishing activity (interviews, estimated pot months (PM) km-2 yr1), and hotspots (based on 50 percent volume contour) for observed (blue) and perceived (yellow) fishing activity, and overlap (horizontal stripe). Maps show four ports: Blyth (a, e, i), Amble (b, f, j), Seahouses (c, g, k) and Holy Island (d, h, l). Grid cells with values of zero are not shown.

\subsection{Agreement between datasets}

The two datasets were correlated at each port, suggesting that grid cells similar in terms of perceived fishing activity were also similar in terms of observed fishing activity (Table 3), however the strength of correlation varied between ports, being lowest at Seahouses and highest at Holy Island (Mantel statistic; Table 3). The greatest spatial coincidence between fishing hotspots mapped by the two datasets was at Amble (overlap as \% of hotspot area; Table 3). The lowest overlap was at Seahouses, where hotspots extend further offshore than in other ports and both 
interview and sightings data showed the least spatially aggregated distribution. At Holy Island, the spatial distribution of sightings data was highly aggregated, and the hotspot identified through analysis of sightings data was completely contained within the hotspot identified through interview data (Figure 3). Both measures of consistency suggested that agreement between the datasets was higher where there was greater aggregation in mapped fishing activity (Table 3).

\section{Discussion}

This research highlights some of the relative merits and limitations of two available data sources currently used to inform fisheries management and marine conservation planning. The methods illustrate an approach to assessing the consistency of datasets in describing the spatial distribution of activity and identifying hotspots, which could be applied in other areas to compare and integrate available data.

\subsection{Distribution of fishing activity}

\subsubsection{Fishing grounds: extent and aggregation}

Both datasets showed similar patterns of potting activity ranges, showing high concentrations of fishing activity in inshore areas near each port. These findings support studies showing that fishing grounds may be closely tied to communities $[46,68]$, and are consistent with the presence of some degree of territoriality in Northumberland lobster fishing communities [70]. In collating marine spatial data the human aspect of resource use at sea is often dissociated from communities on land (e.g. fishing activity may be represented by a GIS layer representing fishing intensity) [4]. Linking fishing grounds to particular resource users is important to help predict and minimise social impacts of MSP. Failure to account for the social context may lead to conflict as a result of spatial displacement of fishing activity, increased congestion, and disruption of customary or informal allocation of fishing grounds $[11,68]$, particularly where there is a lack of flexibility in fishers' spatial patterns $[15,71]$.

The greater extent of fishing grounds mapped by interview data in comparison to sightings may be explained by three factors. Firstly, the use of the 95 percent volume contour to estimate home ranges for sightings data may exclude sightings of vessels in peripheral fishing grounds used by a minority of individuals, as well as excluding positional errors or cases of vessel mis-identification. Secondly, as patrols are driven by enforcement needs, peripheral fishing grounds are likely to receive less coverage, and vessels close inshore may be more often sighted than those fishing towards district limits. Analyses of sightings data attempted to account for the trend in declining patrol coverage observed from the south to the north of the district, and there was no evidence of a corresponding geographical pattern in the strength of the agreement between the two datasets. Holy Island had the lowest frequency of patrols, yet the correlation between sightings data and interview data was strongest at this port. However, lower patrol effort in peripheral fishing grounds around Holy Island may account for the smaller home range and highly aggregated pattern of recorded sightings. Thirdly, vessels with more consistent fishing habits may find it easier to represent their activities on a chart than those who are more exploratory and variable in their behaviour. As a result there may be greater inaccuracies in the mapping of offshore fishing grounds that are used more inconsistently, for example due to greater variability in target species abundance and accessibility in poor weather. This methodological issue has also been raised in the context of mapping different types of fisheries; for example mapping extensive and variable activities such as trawling may present a greater challenge than mapping inshore potting where fishing grounds are relatively small and defined [35].

\subsubsection{Fishing hotspots}


The sizes and shapes of hotspots resulted partly from the choice of parameters in the kernel density estimation, and do not represent definitive boundaries [47]. Nevertheless, the use of identical parameters for both datasets allowed hotspots to be directly compared. A significant degree of overlap occurred between perceived and observed hotspots, particularly in the case of larger hotspots. Similar findings have emerged from studies comparing hotspots of perceived and scientifically measured ecological value in the marine environment, with consistent identification of major hotspots, but greater inconsistencies in the case of minor hotspots [47]. The concentration of $50 \%$ of fishing activity within under a third of mapped fishing grounds estimated by sightings and interview data supports the contention that it may be possible to achieve relatively large no-fishing areas with comparatively small declines in catch [72], assuming that areas of lower fishing pressure are of equal conservation value [73].

At Seahouses, hotspots covered a larger area and extended further out to sea than at other ports, and fishing activity was more dispersed. This may be related to the distribution of suitable habitat in this area, which is more extensive and reaches further out to sea than at other ports. With increasing distance from port, available fishing areas increase exponentially, assuming that suitable habitat is available [40], therefore fishing activity further offshore may be expected to be less aggregated than in areas close inshore. Further south towards Amble and particularly Blyth, suitable potting habitat is less prevalent and more limited to areas close inshore (local fishers, pers. comm., 2009). In these areas trawl vessels are able to work further inshore, further restricting the movement of potting vessels offshore through the risk of gear damage. Different spatial patterns of fishing effort among different fishing communities have been noted elsewhere [68]. The size, shape and frequency of use of fishing grounds may be affected by the distribution of suitable habitat and distance from port, as well as other factors such as seasonal variation in target species and fishing conditions, fuel costs, vessel capabilities, and skippers' knowledge.

Three methodological issues may also have contributed to inconsistencies between hotspots identified by the two datasets. First, while observed hotspots were based on the distribution of individual vessel sightings, hotspots mapped from interview data assumed each fisher's activity to be distributed evenly across reported fishing grounds, which may not be the case. Second, the assumption that where grounds of individuals overlap, fishing effort is the sum of that of the individuals in that area, may be unrealistic; overlap of fishing grounds may result in either higher fishing effort (fishers attracted to particularly good fishing grounds) or lower fishing effort (due to competition between vessels and conflict avoidance). Third, in producing kernel density estimates from sightings data, pooling data from several years allowed analysis of data from smaller ports with fewer vessels. These methods may mask seasonal variability and inter-annual change in the distribution of fishing activity; however data between all years were found to be correlated, and several studies have found the spatial distribution of fishing activity to remain similar over time $[19,22,68]$.

\subsection{Agreement between datasets}

This analysis goes beyond comparing extent of fishing grounds to compare the relative intensity of fishing activity between datasets. Mantel statistics at each port indicated consistency between distribution of observed and perceived fishing activity, although the strength of correlation between distance matrices varied among ports. Key questions for further research include the implications of the strength of relationship between the data sources for the degree of confidence held by managers in using such data for MSP.

Differences in the strength of correlation between sightings and interview data among ports may be related to differences in the underlying spatial pattern of fishing effort distribution. Fishing activity at all ports was aggregated, as is common in studies of fishing effort distribution $[25,69,74]$. However, in ports where the dispersion coefficient indicated a higher degree of aggregation, the Mantel statistic showed a greater degree of similarity in the distribution of fishing activity among the two data sources. The apparent relationship between the strength of agreement between the two datasets and level of aggregation in fishing activity suggests that one or both methods 
of data collection and analysis may be less effective at capturing the spatial distribution of fishing activity where there is a greater degree of dispersion. With regard to vessel sightings, concentration of patrol effort in areas of high fishing activity or persistent byelaw infringements may mean that activity in ports where fishing is more dispersed is less accurately captured than in areas where there is greater aggregation. In the case of interview data, the intensity of fishing activity may be underestimated where fishers mark large areas on charts to indicate areas of "patchy" ground fished further offshore.

Potential limitations and biases in both vessel sightings and interview data make it difficult to assess which of dataset best represents the reality of fishing activity distribution. Sightings data may provide a better understanding of the fine-scale density of fishing activity, but may fail to capture extremes of fishers' spatial behaviour. Conversely, interpreting the distribution of fishing effort across interview-based mapped fishing grounds presents a challenge, but interview data may be more effective at capturing the absolute extent of grounds important to fishers.

Peripheral fishing areas, though less intensively used than fishing hotspots, may be vital to sustaining the capacity of fishers to adapt and respond to changes in resources throughout the year [75]. For instance, during the winter, many Northumberland fishers move offshore to more variable and patchy grounds, where achieving a profit may depend on the ability to move frequently in response to localised abundances. This highlights the importance of taking into account variability in fishers' behaviour when using spatial data to inform MSP. Engagement with resource users is essential to understand sources of variability and uncertainty, and drivers of change in behaviour. Furthermore, variability of responses among fishers, difficulties in representing uncertainty, and assumptions regarding the distribution of activity over mapped areas mean that validation of the maps produced in consultation with the fishing community is imperative. While interview data are often used as a substitute where scientific data are lacking, the value of bringing together scientific and local knowledge to support management decisions is wellrecognised $[19,38,47,49,68]$. Combining the two data sources using GIS offers potential to incorporate the relative merits of both approaches to inform MSP. However, even the most 'accurate' maps may not represent the full reality of fishing behaviour, and interaction with fishing communities is essential to incorporate qualitative information on decision-making and spatial behaviour [76].

\section{Conclusion}

Vessel sightings and interview data both provided similar fine-scale information on the distribution of fishing activity. This emphasises how low-technology, cost-effective interview-based methods in combination with GIS systems allow identification of fishing effort distribution. Understanding the spatial distribution of inshore fisheries is critical to the success of future MSP and fisheries management, with particular implications currently for the designation of a network of marine protected areas. Given the current lack of coverage by VMS data for inshore fleets, data from vessel sightings and interview methods are the primary sources of data available for information on the distribution of inshore fleet activity in the UK. Interview data are likely to be valuable in areas where vessel sightings are especially sparse, patchy or biased in their spatial or temporal coverage.

Agreement between the data sources may depend on the underlying patterns of resource use, and vessel sightings are likely to better represent variable intensity of fishing activity, while interview data may more accurately capture the spatial extent of activity. Engagement with resource users is essential to gain an understanding of the drivers of resource distribution, and triangulation of both datasets is recommended to inform marine spatial management measures alongside qualitative data on fishers' behaviour.

\section{Acknowledgements}

This material is based on work supported by a NERC-ESRC studentship. The authors thank the Northumberland lobster fishers for their support and participation in the research, and Fishery Officers at NIFCA for their assistance.

\section{References}


[1] Botsford LW, Castilla JC, Peterson CH. The Management of Fisheries and Marine Ecosystems. Science (80- ) 1997;277:509-15.

[2] Hughes TP, Bellwood DR, Folke C, Steneck RS, Wilson JA. New paradigms for supporting the resilience of marine ecosystems. Trends Ecol Evol 2005;20:380-6.

[3] Halpern BS, Diamond J, Gaines S, Gelcich S, Gleason M, Jennings S, et al. Near-term priorities for the science, policy and practice of Coastal and Marine Spatial Planning (CMSP). Mar Policy 2012;36:198-205.

[4] Ehler C, Douvere F. Visions for a Sea Change. Report of the First International Workshop on Marine Spatial Planning. Paris: UNESCO: Intergovernmental Oceanographic Commission and Man and the Biosphere Programme. IOC Manual and Guides, No. 46, IOCAM Dossier 3; 2007.

[5] Halpern BS, Walbridge S, Selkoe K a, Kappel C V, Micheli F, D'Agrosa C, et al. A global map of human impact on marine ecosystems. Science 2008;319:948-52.

[6] Pascual M, Borja a., Galparsoro I, Ruiz J, Mugerza E, Quincoces I, et al. Total fishing pressure produced by artisanal fisheries, from a Marine Spatial Planning perspective: A case study from the Basque Country (Bay of Biscay). Fish Res 2013;147:240-52.

[7] Stewart KR, Lewison RL, Dunn DC, Bjorkland RH, Kelez S, Halpin PN, et al. Characterizing fishing effort and spatial extent of coastal fisheries. PLoS One 2010;5:e14451.

[8] Vignaux M. Analysis of vessel movements and strategies using commercial catch and effort data from the New Zealand hoki fishery. Can J Fish Aquat Sci 1996;53:2126-36.

[9] Salthaug A, Aanes S. Catchability and the spatial distribution of fishing vessels. Can J Fish Aquat Sci 2003;268:259-68.

[10] Richardson EA, Kaiser MJ, Edwards-Jones G, Possingham HP. Sensitivity of Marine-Reserve Design to the Spatial Resolution of Socioeconomic Data. Conserv Biol 2006;20:1191-202.

[11] Valcic B. Spatial policy and the behavior of fishermen. Mar Policy 2009;33:215-22.

[12] Wilen JE, Smith MD, Lockwood D, Botsford LW. Avoiding surprises: incorporating fisherman behavior into management models. Bull Mar Sci 2002;70:553-75.

[13] Hilborn R. Managing fisheries is managing people: what has been learned? Fish Fish 2007;8:285-96.

[14] Fulton EA, Smith ADM, Smith DC, van Putten IE. Human behaviour: the key source of uncertainty in fisheries management. Fish Fish 2011;12:2-17.

[15] Teh LCL, Teh LSL, Meitner MJ. Preferred Resource Spaces and Fisher Flexibility: Implications for Spatial Management of Small-Scale Fisheries. Hum Ecol 2012;40:213-26.

[16] Jones PJS. Equity, justice and power issues raised by no-take marine protected area proposals. Mar Policy 2009;33:759-65.

[17] Hilborn R, Ledbetter M. Analysis of the British Columbia salmon purse-seine fleet: dynamics of movement. J Fish Res Board Canada 1979;36:384-91.

[18] Branch TA, Hilborn R, Haynie AC, Fay G, Flynn L, Griffiths J, et al. Fleet dynamics and fishermen behavior: lessons for fisheries managers. Can J Fish Aquat Sci 2006;63:1647-68. 
[19] Hall GB, Moore A, Knight P, Hankey N. The extraction and utilization of local and scientific geospatial knowledge within the Bluff oyster fishery, New Zealand. J Environ Manage 2009;90:2055-70.

[20] Jentoft S, Knol M. Marine spatial planning: Risk or opportunity for fisheries in the North Sea? Marit Stud 2014;12:13.

[21] Hutton T, Mardle S, Pascoe S, Clark RA. Modelling fishing location choice within mixed fisheries: English North Sea beam trawlers in 2000 and 2001. ICES J Mar Sci 2004;61:1443-52.

[22] Rijnsdorp AD, Buys AM, Storbeck F, Visser EG. Micro-scale distribution of beam trawl effort in the southern North Sea between 1993 and 1996 in relation to the trawling frequency of the sea bed and the impact on benthic organisms. ICES J Mar Sci 1998;55:403-19.

[23] Andersen B, Christensen A-S. Modelling short-term choice behaviour of Danish fishermen in a mixed fishery. In: Sumaila UR, Marsden AD, editors. North Am. Assoc. Fish. Econ. Forum Proceedings. Fish. Cent. Res.

Reports 14(1), vol. 14, Vancouver, Canada: Fisheries Centre, University of British Columbia; 2006, p. 13-26.

[24] Greenstreet SPR, Holland GJ, Fraser TWK, Allen VJ. Modelling demersal fishing effort based on landings and days absence from port, to generate indicators of "activity." ICES J Mar Sci 2009;66:886-901.

[25] Jennings S, Alvsvag J, Cotter AJR, Ehrich S, Greenstreet SP, Jarre-Teichmann A, et al. Fishing effects in northeast Atlantic shelf seas: patterns in fishing effort, diversity and community structure. III. International trawling effort in the North Sea: an analysis of spatial and temporal trends. Fish Res 1999;40:125-34.

[26] Woolmer A. National Shellfish Resource Base: Cost-effective and efficient methodology to map inshore under 10m fleet. Report to Shellfish Industry Development Strategy; 2009.

[27] Deng R, Dichmont CM, Milton D, Haywood M, Vance D, Hall N, et al. Can vessel monitoring system data also be used to study trawling intensity and population depletion? The example of Australia's northern prawn fishery. Can J Fish Aquat Sci 2005;62:611-22.

[28] Harrington JJ, Semmens JM, Haddon M. Spatial distribution of commercial dredge fishing effort: application to survey design and the spatial management of a patchily distributed benthic bivalve species. Mar Freshw Res 2007;58:756.

[29] Bastardie F, Nielsen JR, Ulrich C, Egekvist J, Degel H. Detailed mapping of fishing effort and landings by coupling fishing logbooks with satellite-recorded vessel geo-location. Fish Res 2010;106:41-53.

[30] Campbell MS, Stehfest KM, Votier SC, Hall-Spencer JM. Mapping fisheries for marine spatial planning: Gearspecific vessel monitoring system (VMS), marine conservation and offshore renewable energy. Mar Policy 2013:1-8.

[31] Mills CM, Townsend SE, Jennings S, Eastwood PD, Houghton CA. Estimating high resolution trawl fishing effort from satellite-based vessel monitoring system data. ICES J Mar Sci 2006;64:248-55.

[32] Witt MJ, Godley BJ. A step towards seascape scale conservation: using vessel monitoring systems (VMS) to map fishing activity. PLoS One 2007;2.

[33] Ban NC, Hansen GJA, Vincent ACJ, Jones M. Systematic marine conservation planning in data-poor regions: Socioeconomic data is essential. Mar Policy 2009;33:794-800.

[34] Scholz A, Bonzon K, Fujita R, Benjamin N, Woodling N, Black P, et al. Participatory socioeconomic analysis: drawing on fishermen's knowledge for marine protected area planning in California. Mar Policy 2004;28:33549. 
[35] Des Clers S, Lewin S, Edwards S, Lieberknecht L, Murphy D. Fishermap. Mapping the Grounds: recording fishermen's use of the seas. Final Report. A report published for the Finding Sanctuary project; 2008.

[36] Ardron J, Marchand A, Liedtke M. Gathering Spatial Knowledge from Local Experts: A Handbook for Interviewing Fishermen. Sointula, BC, Canada: Living Oceans Society; 2005.

[37] Bergmann M, Hinz H, Blyth RE, Kaiser MJ, Rogers SI, Armstrong M. Using knowledge from fishers and fisheries scientists to identify possible groundfish "Essential Fish Habitats." Fish Res 2004;66:373-9.

[38] Brown G, Smith C, Alessa L, Kliskey A. A comparison of perceptions of biological value with scientific assessment of biological importance. Appl Geogr 2004;24:161-80.

[39] Mellado T, Brochier T, Timor J, Vitancurt J. Use of local knowledge in marine protected area management. Mar Policy 2014;44:390-6.

[40] Caddy JF, Carocci F. The spatial allocation of fishing intensity by port-based inshore fleets: a GIS application. ICES J Mar Sci 1999;56:388-403.

[41] Aswani S, Hamilton RJ. Integrating indigenous ecological knowledge and customary sea tenure with marine and social science for conservation of bumphead parrotfish ( $<1>$ Bolbometopon muricatum $</ \mid>)$ in the Roviana Lagoon, Solomon Islands. Environ Conserv 2004;31:69-83.

[42] Aswani S, Lauer M. Incorporating Fishermen's Local Knowledge and Behaviour into Geographical Information Systems (GIS) for Designing Marine Protected Areas in Oceania. Hum Organ 2006;65:81-102.

[43] Hall GB, Close $\mathrm{CH}$. Local knowledge assessment for a small-scale fishery using geographic information systems. Fish Res 2007;83:11-22.

[44] Lauer M, Aswani S. Integrating indigenous ecological knowledge and multi-spectral image classification for marine habitat mapping in Oceania. Ocean Coast Manag 2008;51:495-504.

[45] De Freitas DM, Tagliani PRA. The use of GIS for the integration of traditional and scientific knowledge in supporting artisanal fisheries management in southern Brazil. J Environ Manage 2009;90:2071-80.

[46] Weeks R, Russ GR, Bucol AA, Alcala AC. Shortcuts for marine conservation planning: The effectiveness of socioeconomic data surrogates. Biol Conserv 2010;143:1236-44.

[47] Alessa L, Kliskey A, Brown G. Social-ecological hotspots mapping: A spatial approach for identifying coupled social-ecological space. Landsc Urban Plan 2008;85:27-39.

[48] Rochet M-J, Prigent M, Bertrand JA, Carpentier A, Coppin F, Delpech J-P, et al. Ecosystem trends: evidence for agreement between fishers' perceptions and scientific information. ICES J Mar Sci 2008;65:1057-68.

[49] Ban NC, Picard CR, Vincent ACJ. Comparing and Integrating Community-Based and Science-Based Approaches to Prioritizing Marine Areas for Protection. Conserv Biol 2009;23:899-910.

[50] Phillipson J, Symes D. Great Britain. In: Symes D, Phillipson J, editors. Inshore Fish. Manag., Dordrecht, The Netherlands: Kluwer Academic Publishers; 2001.

[51] MFA. UK Sea Fisheries Statisctics 2008. Marine and Fisheries Agency, DEFRA, London. Available online: www.marinemanagement.org.uk/fisheries/statistics/documents/ukseafish/2008/final.pdf [Accessed June 2010]; 2008. 
[52] Parliamentary Office of Science and Technology. Selection of Marine Conservation Zones. Postnote, Number 437, June 2013; 2013.

[53] Defra. New network to protect valuable marine life. UK Government Department for Environment, Food and Rural Affairs press release, 21 November 2013, URL: https://www.gov.uk/government/news/new-networkto-protect-valuable-marine-life; 2013.

[54] Natural England, JNCC. Marine Conservation Zone Project: Additional guidance for regional MCZ projects on planning for areas where licensed, planned or existing socio-economic activities occur. Natural England / Joint Nature Conservation Committee (JNCC); 2010.

[55] Klein CJ, Chan A, Kircher L, Cundiff AJ, Gardner N, Hrovat Y, et al. Striking a balance between biodiversity conservation and socioeconomic viability in the design of marine protected areas. Conserv Biol 2008;22:691700 .

[56] Bennett TL, Foster-Smith JL. South-east Scotland and north-east England (Dunbar to Bridlington) (MNCR Sector 5). In: Hiscock K, editor. Mar. Nat. Conserv. Rev. Benthic Ecosyst. Gt. Britain north-east Atl., Peterborough: JNCC; 1998, p. 155-76.

[57] DEFRA. Aln Estuary Marine Conservation Zone. UK Department for Environment Food and Rural Affairs; 2013.

[58] ESRI. ArcGIS version 9.2. Redlands, California, USA: Environmental Systems Research Institute; 2006.

[59] Clark R. Sussex inshore fisheries. Part I: The inshore fisheries off the Sussex coast: A description of the methods and spatial extents, 2004-2007. Shoreham-by-Sea, Sussex: Sussex Sea Fisheries Committee Report; 2008.

[60] Oksanen J, Kindt R, Legendre P, O'Hara B, Simpson GL, Solymos P, et al. vegan: Community Ecology Package. R Package Version 1.5-4: Available at http://CRAN.R-project.org/package=vegan; 2009.

[61] R Core Team. R: A language and environment for statistical computing. Vienna, Austria: R Foundation for Statistical Computing; 2013.

[62] Goslee SC, Urban DL. The ecodist package for dissimilarity-based analysis of ecological data. J Stat Softw 2007;22:1-19.

[63] Legendre P, Legendre L. Numerical Ecology. Amsterdam: Elsevier; 1998.

[64] Beyer HL. Hawth's Analysis Tools for ArcGIS. Available at www.spatialecology.com/htools [Accessed June 2008]; 2004.

[65] Bailey T, Gatrell T. Interactive Spatial Data Analysis. Prentice Hall; 1995.

[66] Van Winkle W. Comparison of Several Probabilistic Home-Range Models. J Wildl Manage 1975;39:118-23.

[67] Bunce L, Townsley P, Pomeroy RS, Pollnac RB. Socioeconomic Manual for Coral Reef Management. GCRMN/IUCN/AIMS/NOAA, AIMS, Townsville: www.aims.gov.au/pages/reflib/smcrm/mcrm-000.html; 2000.

[68] St. Martin K, Hall-Arber M. The missing layer: Geo-technologies, communities, and implications for marine spatial planning. Mar Policy 2008;32:779-86.

[69] Pet-Soede C, van Densen WLT, Hiddink JG, Kuyl S, Machiels MAM. Can fishermen allocate their fishing effort in space and time on the basis of their catch rates? An example from Spermonde Archipelago, SW Sulawesi, Indonesia. Fish Manag Ecol 2001;8:15-36. 
[70] Turner RA, Gray T, Polunin NVC, Stead SM, Stead M. Territoriality as a Driver of Fishers' Spatial Behavior in the Northumberland Lobster Fishery. Soc Nat Resour 2013;26:1-15.

[71] Weeks R, Russ GR, Bucol AA, Alcala AC. Incorporating local tenure in the systematic design of marine protected area networks. Conserv Lett 2010;00:1-9.

[72] Ban NC, Vincent ACJ. Beyond marine reserves: exploring the approach of selecting areas where fishing is permitted, rather than prohibited. PLoS One 2009;4:e6258.

[73] Margules CR, Pressey RL. Systematic conservation planning. Nature 2000;405:243-53.

[74] Daw TM. Spatial distribution of effort by artisanal fishers: Exploring economic factors affecting the lobster fisheries of the Corn Islands, Nicaragua. Fish Res 2008;90:17-25.

[75] Salas S, Gaertner D. The behavioural dynamics of fishers: management implications. Fish Fish 2004;5:153-67.

[76] Smith G, Brennan RE. Losing our way with mapping: Thinking critically about marine spatial planning in Scotland. Ocean Coast Manag 2012;69:210-6. 